\title{
Ada Ferrer
}

Freedom's Mirror: Cuba and Haiti in the Age of Revolution. Cambridge: Cambridge University Press, 2014. xiv + 377 pp. (Paper US\$29.99)

Scholars have long identified the Haitian Revolution as a turning point in the history of slavery in the Americas, a moment that ushered in ideologies of general emancipation as well as the entrenchment of more industrialized forms of human bondage. Freedom's Mirror evocatively explores this tension between turn-of-the-nineteenth-century radical ideologies of freedom emanating out of Haiti and the rise of "second slavery" in Cuba. ${ }^{1}$ In an effort to dispel the idea that the Haitian Revolution's presence in the Caribbean was confined to the symbolic field, Ada Ferrer illuminates concrete networks of exchange that proliferated between Cuba and Saint-Domingue after 1791. Partially helped by a diminished competitor, African captives, sugar-making machinery, and expertise imported from its convulsing neighbor, Cuba expanded its presence in the world sugar markets soon after the beginning of slave unrest on Hispaniola. But knowledge of the slave insurgency also trickled through the networks connecting Cuba and Saint-Domingue. "Freedom's mirror" is therefore a playful metaphor, for if Cuba's sugar revolution emerged out of Saint-Domingue's freedom struggle (and, as such, like any mirror projection, reversed the structure of the projected object), it also inadvertently carried within itself abolitionist radicalism. The book's first four chapters focus on the connections between Saint-Domingue and Cuba during the revolutionary tumult on Hispaniola; the final three examine the impact of these links after Haitian independence, during debates over Latin American independence and the abolition of the slave trade in the Cortes de Cádiz.

Ferrer incorporates popular and elite politics to show that the transition from first to second slavery was fundamentally fraught, lacking the neatness that an economic narrative might suggest. Through its exploration of subaltern politics, Freedom's Mirror expands a growing corpus of intellectual and political histories of Afro-descendants. Ferrer pieces together evidence for the way Haiti might have triggered a revolution in black consciousness in Cuba. She therefore takes on the challenge of teasing out Afro-descendants' political and intellectual worlds from records whose elite authors deployed the prospect of a generalized slave insurrection to garner more concessions from the Spanish Crown. Her meditative and novel engagement with the Aponte conspiracy points to yet another challenge posed by this kind of history: the

1 On "second slavery," see Chapter 3 of Dale Tomich, Through the Prism of Slavery (2004).

(C) ADRIANA CHIRA, 2016 | DOI: $10.1163 / 22134360-09003020$

This is an open access article distributed under the terms of the Creative Commons

Attribution-Noncommercial 3.0 Unported (CC-BY-NC 3.0) License. 
ambiguous forms through which slaves and free people of color transmitted subversive knowledge. The peculiarly associative language resists the historian, as it resisted colonial authorities two centuries ago. In 1812, the authorities discovered an antislavery plot that implicated plantation slaves and free people of color, some of them with roots in Saint-Domingue. At the center of this plot was José Antonio Aponte, a free man of color and member of the black militia. The authorities discovered a book of paintings by him depicting loosely associated historical events. While the book is missing from the archival record, we have an account of Aponte's explanations of the drawings during a lengthy interrogation. The book ambiguously situated Blacks at the center of history, as kings and prophets. But images of Ethiopia were interspersed among drawings of "Apollo and Neptune; Mars and Gemini; Spanish politicians and kings" (p. 311). Ferrer masterfully draws out Aponte's savvy use of ambiguity and historical reference to conceal an entire political world from the interrogator. Moreover, she argues, Aponte and his supporters were plotting right as the abolition of the slave trade was being debated in the Cortes de Cádiz, as Henri-Christophe had been crowned king of Haiti, and his navy had been intercepting boats carrying slaves to Cuba, and as rumors of returning Saint-Domingue black auxiliaries who had fought with the Spanish in Santo Domingo were crossing Havana. These events were not just background for the conspiracy, Ferrer suggests: rather, the conspirators had carefully analyzed them and incorporated them as legitimating propaganda for their cause.

Freedom's Mirror is a masterful meditation on economic and political revolutions; as such, it opens up a wealth of questions and methodological avenues for scholars of the Caribbean. The protagonists of this account are male figures, involved in military projects. One topic that might deserve future exploration is the role of gender ideologies in these figures' conceptions of the free or enslaved subject and of diasporic community-making. The focus on transimperial exchanges between Cuba and Haiti occasionally alludes to the geographic integration of other sites within these networks of exchange, most notably the neighboring British territories or the Spanish mainland. Future research might consider at greater length how these other areas mediated the exchanges between Cuba and Haiti. Was the Cuba-Haiti mirroring relationship unique? Freedom's Mirror is bound to become a classic of Caribbeanist historiography; its methodological sophistication and enthralling narrative will impact scholarship on slave and postslave societies and on subaltern politics well beyond this region.

\section{Adriana Chira}

Department of History, University of Michigan, Ann Arbor MI 48109, U.S.A. achira@umich.edu 